Volume 8 , Issue 2

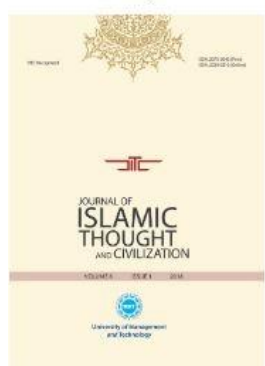

Journal of Islamic Thought and Civilization (JITC)

Volume 8, Issue 2, Fall 2018

ISSN: 2075-0943, eISSN: 2520-0313

Journal DOI: https://doi.org/10.32350/jitc

Issue DOI: https://doi.org/10.32350/jitc.82

Homepage: https://www.umt.edu.pk/jitc/home.aspx

Journal QR Code:
Article:

Author(s):

Online

Published:

Article DOI:

Article QR

Code:

To cite this article:

Copyright Information

\section{Peaceful Coexistence of Various Religious Groups in Islam; Some Examples from the History of Muslim Societies}

\author{
Md. Thowhidul Islam
}

Fall 2018

\section{https://doi.org/10.32350/jitc.82.11}

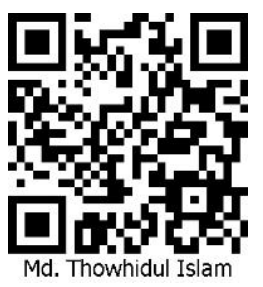

Islam, Md. Thowhidul. "Peaceful coexistence of various religious groups in Islam: Examples from the history of Muslim societies." Journal of Islamic Thought and Civilization 8, no. 2 (2018): 183-203. \section{Crossref}

This article is open access and is distributed under the terms of Creative Commons Attribution - Share Alike 4.0 International License

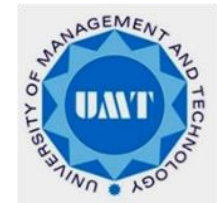

A publication of the

Department of Islamic Thought and Civilization

School of Social Science and Humanities

University of Management and Technology

Lahore, Pakistan.
Indexing Partners

INDEX

ISLAM I CUS

(15)

Crossref

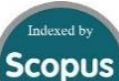

Scopus

5 . WorldCat

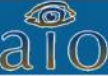

GENERALIMPACTFACTOR

INDEX COPERNICUS
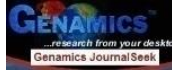

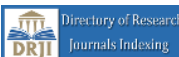

$\mathrm{R} \partial \mathrm{AD}=$

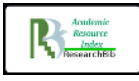

8

For more, please

click here 


\title{
Peaceful Coexistence of Various Religious Groups in Islam; Some Examples from the History of Muslim Societies
}

\author{
Md. Thowhidul Islam* \\ Bangladesh Studies, \\ International Islamic Univerity, \\ Chittagong, Bangladesh
}

\begin{abstract}
"O mankind, We created you all from a male and a female, and made you into nations and tribes so that you may know one another." This verse clearly indicates that there should not be any discrimination based on clan, creed, race or religion. The word Islam itself refers to peace. Islamic teachings contain many injunctions for settling disputes between people and nations with the aim of establishing peace. Islamic history shows that Muslims and non-Muslims co-existed in peace in Medina (first Islamic State) and the successive Muslim states. The Charter of Medina, declared by the Prophet Muhammad $(S A W)$ in 622 A.D., is the best example to establish communal coexistence of different beliefs. This policy was also exercised by successive rulers of different Muslim territories in the history of Islamic world. Unfortunately, establishing peaceful coexistence has now become a challenge in the world. Several Muslim countries have been suffering from internal conflict and resistance even among the different Muslim groups. Hence, the review of Islamic attitude towards coexistence is deemed significant. Within this context, the paper aims at exploring the view of Islam towards the peaceful coexistence of various religious groups with some examples from the history of Muslim societies particularly during the early time period of Islam. The methodology used in this conceptual study is the critical analysis of literature surveyed on the concept of Islam regarding the peaceful coexistence of religions and its practice in the history of Muslim societies.
\end{abstract}

Keywords: Islam, peaceful coexistences, human rights, religious diversity, Muslim society

\section{Introduction}

Peaceful coexistence among diverse groups of people belonging to different religions, ethnicities, tribes, races, colors, languages, nationalities etc. has undoubtedly been considered a pre-condition of social security and global peace. It has been characterized also as an important element for ensuring human rights. Since the beginning of history, mankind has been struggling to find peace and has developed many principles and covenants to establish social peace. Among the famous international covenants Magna Carta (1215), ${ }^{2}$ Covenant of the League of Nations (1919), ${ }^{3}$ the General

\footnotetext{
*Correspondence concerning the article should be addressed to Muhammad Thowhidul Islam, Assistant Professor, Bangladesh Studies, International Islamic University Chittagong (Bangladesh), tauhidcox@yahoo.com

${ }^{1}$ Qur'ān al-Hujurāt 49:13.

${ }^{2}$ Magna Carta is one of the most famous documents in the world history, issued by King John of England (r.1199-1216). For the first time, it established the principle that everybody, including the king, was subject to the law. Although nearly a third of the text was deleted or rewritten, and almost all the clauses have been repealed in modern times, Magna Carta remains a
} 
Treaty for the Renunciation of War (1928) ${ }^{4}$ and the Charter of United Nations (1945) ${ }^{5}$ are remarkable. Despite the fact that these conventions have been signed by a majority of nations, it has been very rare that their intended peace is established in societies across the world and thus these conventions have failed to achieve their desired goal. In recent times, intolerant attitude among different religious groups has significantly increased in different parts of the world. Peaceful coexistence has become a challenge for global peace and security, particularly in many Muslim countries. The Middle-Eastern countries, several countries of Africa, South and South-East Asia are suffering from internal resistance and intolerant attitude of different groups often culminating in civil war and terrorist attacks against their populace. Consequently, Muslims are occasionally characterized as 'terrorists.' Within this global context, it is worthy to explore the original views of Islam towards coexistence and tolerance among diverse religious groups and even among different groups in the Muslim society itself. Moreover, it is also worthy to explore what Muslim history tells us about peaceful coexistence keeping in view the examples set during its golden periods.

Islam identifies diversity among human beings as a sign of God, beauty of creation, and rejects any discrimination among communities based on religious, racial, linguistic and national grounds. Muslims should believe in all the revealed books, that is, the Torah, Psalms and Gospel as the books of God revealed to Moses, David and Jesus $(A S)$, respectively. They should believe in all prophets like Prophet Muhammad $(S A W)$ as messengers of God. Islam contains many injunctions for social behavior, communal responsibilities, settling disputes and resolving conflicts with the aim of establishing peaceful coexistence. Islamic history evidently shows that Muslims and non-Muslims lived together peacefully in Medina, the first Islamic State and in its successive states in the early history of Islam. The Charter of Medina declared by the Prophet Muhammad $(S A W)$ in 622 A.D. aimed at governing a multi-religious pluralistic society that allowed religious freedom for all and set the best ever example in history for the coexistence of different religious groups. Different communities with different religions that had shown enmity towards one another for several decades became parties to this pact and started to

cornerstone of the British constitution. For details, see the British library: https:/www.bl.uk/magna-carta/articles/magna-carta-an-introduction (Accessed August 28, 2018).

${ }^{3}$ The Covenant of the League of Nations was formed at the end of $1^{\text {st }}$ World War to establish global peace and security. The charter was approved on $11^{\text {th }}$ April, 1919. For details, see the Encyclopedia Britannica: https://www.britannica.com/topic/League-of-Nations\#ref337581 (Accessed August 28, 2018).

${ }^{4}$ General Treaty for Renunciation of War is a 1928 international agreement in which signatory states promised not to use war to resolve 'disputes or conflicts of whatever nature or of whatever origin they may be, which may arise among them'. It also known as 'Kellogg-Briand Pact'. For details, see the Encyclopedia Britannica: https://www.britannica.com/event/KelloggBriand-Pact (Accessed August 28, 2018).

${ }^{5}$ The Charter of the United Nations was signed on $26^{\text {th }}$ June, 1945 , and came into force on 24 October 1945. The Charter outlined a broad set of principles relating to achieving 'higher standards of living,' addressing 'economic, social, health, and related problems,' and 'universal respect for, and observance of, human rights and fundamental freedoms for all without distinction as to race, sex, language, or religion.' For details, see the UN: http://www.un.org/en/charterunited-nations/ (Accessed August 28, 2018).

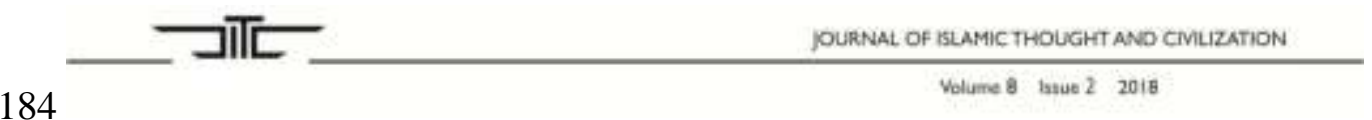


live together peacefully. With this document, the tribal structure based on blood and kinship was abolished and people of different cultural, ethnic and religious groups formed a single society. Many other such treaties concluded by the Prophet $(S A W)$ aimed at ensuring peaceful coexistence. The four pious Caliphs (632-661 A.D.), the Umayyads (661-750 A.D.), the Abbasids (750-1258 A.D.), the Fatimids in Egypt (969-1171 A.D.) and the Muslims in Spain (711-1492 A.D.) strictly followed the policy of the Prophet Muhammad $(S A W)$ and set a good number of examples in the history of Islam of fostering peaceful coexistence. The paper explores the theoretical views of Islam towards peaceful coexistence by taking note of some examples from the history of Muslim societies. The methodology used in this conceptual study is a critical analysis of literature surveyed for this purpose. The literature about the concept of Islam regarding peaceful coexistence and its practices in the history of Muslim societies is surveyed to understand the injunctions of Islam in this regard and their practical implementation.

\section{Defining Peaceful Coexistence}

Coexistence is a state in which two or more groups live together, respecting their differences and resolving their conflicts in a nonviolent manner. ${ }^{6}$ It is "to exist together at the same time or in the same place and also to live in peace with others despite differences, especially as a matter of policy.", Coexistence refers to "a way for groups of different faith, ideology, and background to live together peacefully with mutual understanding and tolerance of each other.",

Its basic characteristics are as follows:

To exist together at the same time and in the same place and to exist in mutual tolerance.

To learn to recognize and live with differences. ${ }^{10}$

To develop a relationship between persons or groups in which none of them tries to destroy the other(s).

To interact with a commitment to tolerance, mutual respect, and an agreement to settle conflicts without recourse to violence.

\footnotetext{
${ }^{6}$ Eugene Weiner, “Coexistence Work: A New Profession," in The Handbook of Interethnic Coexistence, ed., Eugene Weiner (New York: Continuum International Publishing Group, 1998), 13-24.

TMerriam Webster Dictionary, Accessed February 28, 2017, https://www.merriam-webster.com/dictionary/coexistence

${ }^{8}$ Abdur Rahman Toyese Adesokan, "An Appraisal of Peaceful Coexistence between Muslims and Non-Muslims in Houston Texas of USA," E-Journal of Arabic Studies and Islamic Civilization 2 (2015): 48. http://WorldConferences.net. Accessed February 28, 2017.

${ }^{9}$ Cambridge Dictionary, s.v. "Coexistence,"; Oxford Dictionary, s.v. "Coexistence."

${ }^{10}$ Kumar Rupesinghe, "Coexistence and Transformation in Asia: Some Reflections," In Culture and Identity: Ethnic Coexistence in the Asian Context, ed., Kumar Rupsinghe, (Washington, D.C.: The Sasakawa Peace Foundation, 1999), 3-37.

${ }^{11}$ Louis Kriesberg, "Coexistence and the Reconciliation of Communal Conflicts," In The Handbook of Interethnic Coexistence, ed., Eugene Weiner (New York: Continuum International Publishing Group, 1998), 182-198.
} 
Coexistence as a social ingredient is categorized into two types.

\subsection{Active Coexistence}

In this type of coexistence, "Relationships are characterized by a recognition and respect for diversity and an active embrace of difference, equal access to resources and opportunities, and equity in all aspects of life by the individuals and communities. This type of coexistence manifests social peace based on justice, equality, and inclusion. Institutions in this environment are designed to ensure fairness." $" 13$

\subsection{Passive Coexistence}

This type of coexistence refers to "Where individuals and communities merely tolerate other groups and relationships are characterized by unequal power relationships, little inter-group contact, and little equity. The principles of social justice are not apparent and institutions are not designed to support equality. Consequently, unjust and oppressive structures can be maintained. These structures often impede community growth, peace processes, and the development of democracy. Yet, since inter-group conflict is not widespread, the groups can still be said to coexist without violence." 14

A state of coexistence provides physical and psychological conditions for individuals, organizations, and communities to reduce tensions, resolve conflicts and thus establish peace in society. ${ }^{15}$ It respects diversity in the sense that individuals and groups differ from one another in various ways including class, ethnicity, religion, race, gender, nationality etc. The tools of coexistence mitigate group differences, resolve conflicting situations, bar violence, establish justice, increase integration, promote respectful inter-group relationships, create a peaceful environment for individuals and develop community structures based on fairness, justice and equity.

\section{Peaceful Coexistence in Islam}

The word Islam originates from the Arabic root Salam or Silm which means peace and submission to the will of God. Every Muslim is ordered to greet other Muslims with the words "Assalam-o- Alaikum" (peace be upon you). In several verses of the Holy Qur'ān, God refers to Himself as as-Salam or 'Peace.' So, the spirit of peace and harmony is rooted in every norm and value of Islam. Every instruction of Islam, in its true sense, aims at securing peace and creating harmony in every sphere of life and society. Several verses of the Holy Qur'ān and sayings of the Prophet $(S A W)$ promote peaceful coexistence among diverse groups of people. Islamic principles for peaceful coexistence are explained below.

\footnotetext{
${ }^{12}$ The Coexistence Initiative, Organizational Brochure, Accessed February 28, 2017, http://coexist.co.ke/

${ }^{13}$ Angela Nyawira Khaminwa, "Coexistence," in Beyond Intractability, eds. Guy Burgess and Heidi Burgess (Boulder; Conflict Information Consortium, University of Colorado, 2003).

14 Ibid.

${ }^{15}$ Eugene Weiner, “Coexistence Work: A New Profession,” 13-24.

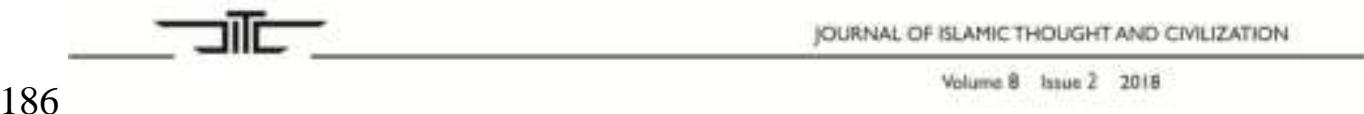




\subsection{Common Origin of Mankind and Respecting Humanity}

All human beings have originated from a single soul and the same parents. The Holy Qur'ān says, "O mankind, indeed We have created you from a male and a female and made you peoples and tribes that you may know one another. Indeed, the most noble of you in the sight of Allah is the most righteous of you. Indeed, Allah is Knowing and Acquainted." 16 This verse combines all nations in a universal union, while each society can maintain its unique identity and characteristics. So, there should not be any discrimination based on creed, clan, race, language, culture or any other grounds. Islam recognizes diversity as a sign of the Creator used for mutual identification and recognition. Hence, it should not lead to any discrimination and conflict. In an Islamic society, a human being has certain duties to and corresponding rights over another irrespective of religion, race or nationality. The Holy Qur'ān says, "If someone kills another person - unless it is in retaliation for someone else or for causing corruption in the earth - it is as if he had murdered all mankind. And if anyone gives life to another person, it is as if he has given life to all mankind." ${ }^{\text {Muhammad }(S A W) \text { in his farewell }}$ address declared that "O people! Verily your Lord is one and your father is one. All of you belong to one ancestry of Adam and Adam was created out of clay. There is no superiority for an Arab over a non-Arab and for non-Arab over an Arab; not for white over the black or not for the black over the white except in piety." 18

\subsection{Believing in Other Revealed Religious Scriptures and Prophets}

Muslims should believe in the Torah (Taurāt) revealed to Moses, the Psalms (Zabūr) revealed to David and the Gospel (Injīl) revealed to Jesus. They should also believe in all other books of God without any exception and all prophets like Prophet Muhammad $(S A W)$ as the messengers of God without any discrimination. The Holy Qur'ān says, "Say, [O believers], 'We have believed in Allah and what has been revealed to us and what has been revealed to Abraham and Ishmael and Isaac and Jacob and the Descendants and what was given to Moses and Jesus and what was given to the prophets from their Lord. We make no distinction between any of them, and we are Muslims [in submission] to Him." "19 The Holy Qur'ān repeatedly refers to the previous religious scriptures and prophets in order to prove that the message of Islam does not differ from that of those books. The Qur'ān says, "He has ordained for you of religion what $\mathrm{He}$ enjoined upon Noah and that which We have revealed to you, [O Muhammad], and what We enjoined upon Abraham and Moses and Jesus to establish the religion and not be divided therein." 20 Instead, Islam confirms the messages of the previous prophets and scriptures and corrects the misinterpretations made by the followers of the earlier prophets. The Qur'ân says, "So woe to those who write the 'scripture' with their own hands, then say, 'This is from Allah,' in order to exchange it for a small price. Woe to them for what their hands have written and woe to them for what they earn." ${ }^{21}$ Thus, the

16 al-Hujurāt 49:13.
17 al-Maida 5:32.
${ }^{18}$ Ibn Ishāq, Sirat-i-Rasulullah, Trans. Shahid Akhanda, Vol. 3 (Dhaka: Islamic Foundation Bangladesh, 1992), 648.

19 an-Nisa 4:152; al-Baqarah 2: 285, 136.

20 ash-Shūra 42:13.

21 al-Baqarah 2:79.

JOUANAL OF ISLAMIC THOUGHT AND CIVILZATION 
mission of the Prophet Muhammad $(S A W)$ was not to establish a new religion; rather it was to clarify the divine message revealed to the earlier prophets and purify it from misinterpretations and infiltrations.

\subsection{Common Beliefs and Values with Ahl-i-Kitāb}

There are many beliefs and values which are common among Muslims and Ahl$e-K i t a \bar{b}$ (People of the Book). Allah Almighty enjoins Muslims to say to Ahl-e-Kitāb, "We believe in that which hath been revealed unto us and revealed unto you; our God and your God is one, and unto Him we surrender."22 The Holy Qur'ān further announces the reward for those from Ahl-e-Kitāb who truly observe the teachings of their religious books. ${ }^{23}$ All the true followers of these great religions believe that God is the creator of the entire universe and He dominates all that exists with His omnipotence. They believe in life-after-death, heaven, hell, and angels. They also believe that besides Jesus, Moses or Muhammad $(S A W)$, God sent many prophets and messengers as Noah, Abraham, Joseph, David, and Solomon $(S A W)$ throughout the course of history. It is lawful for Muslims to eat the meals prepared by Ahl-e-Kitāb and marry their women. ${ }^{24}$

\subsection{Respecting the Places of Worship}

Islam guarantees the protection of the houses of worship of Jews, Christians and other non-Muslims living in the Muslim state and their right to worship according to their faith. The Holy Qur'ān says, "if God had not driven some people back by means of others, monasteries, churches, synagogues and mosques, where God's name is mentioned much, would have been pulled down and destroyed." "25 In fact, the name "Allah" has been used for God by Arabic-speaking Jews and Christians since the beginning of Islam as Jews and Christians worship the same God, however flawed their understanding may or may not be, and thus their worship deserves the protection of law. Even if we assume that the name of Allah is not invoked in the houses of worship of non-Muslims, they would still be entitled to protection as granted by Islam. ${ }^{26}$

\subsection{No Forceful Conversion}

Islam does not allow using force as a means of conversion. "There shall be no compulsion in acceptance of the religion. The right course has become clear from the wrong. So whoever disbelieves in false gods and believes in Allah has grasped the most trustworthy handhold with no break in it. And Allah is Hearing and Knowing." 27 No historical evidence is found in support of forceful conversion during the time of the rapid expansion of Islam in its early history. All Muslim jurists unanimously hold the concept that forced conversion, under any circumstances, is null and void. Any such attempt is a grievous sin in Islam. The Holy Qur'ān says, "Had your Lord wanted, all the people on earth would have believed. Then, [O Muhammad] will you force the people in order that

22 al-Ankabūt 29:46.

23 al-Baqarah 2:62.

24 al-Maida 5:5.

25 al-Hajj 22:40.

${ }^{26}$ Abu Amina Elias, "Permanent Link to Protection of non-Muslim Houses of Worship in Islam," https://abuaminaelias.com/protection-of-non-muslim-houses-of-worship-in-islam/ Accessed May 10, 2017.

27 al-Baqarah 2:256; al-Kafiroon 109:1-6. 
they become believers?" "28“'So warn them: your only task is to warn, you're not supposed to force them." 29 "And if you [people] deny [the message] - already nations before you have denied. And there is not upon the Messenger except [the duty of] clear notification." ${ }^{, 3}$ All the verses make it very clear that no Muslim is allowed to harm a non-Muslim because of differences in religious faith.

\subsection{Islamic Concept of Wasatiyyah (Moderation)}

Wasatiyyah refers to a moderate, just and balanced way of life; the median path between extremes. It implies gentleness, temperateness, calmness and fairness. It is an antidote to harshness, severity, and extremism in all forms. Wasatiyyah is the ideal mean of social interaction for peaceful coexistence, while its absence begets extremism and social unrest. Islam has been termed as a religion of Wasatiyyah and thus a religion of 'middle way between extremes.' Holy Qur'ān says “And thus we have made you a just, balanced and moderate community that you will be witnesses over the people and the Messenger will be a witness over you." ${ }^{31}$ Wasatiyyah is maintained in every Islamic injunction such as between physical and spiritual dimensions, between imān (internal faith) and $a^{\prime} m \bar{a} l$ (outward action), ${ }^{32}$ between huqūq-Allah and huqūq-al-I'bād (rights we owe to God and the rights we owe to the creation), between rights of the individual and consideration for others, between practice and preaching, ${ }^{33}$ between the need for peace and the reasons for war, ${ }^{34}$ between engagement in this world and perception of the Hereafter, ${ }^{35}$ between indulgence and over-indulgence, ${ }^{36}$ between holding one's own views and those who differ, ${ }^{37}$ between religious duty and overzealous religiosity, between abilities and responsibilities, ${ }^{38}$ between over-exertion and underperformance, ${ }^{39}$ etc. The Almighty God desires no difficulty, rather wishes ease for human beings. ${ }^{40}$ Islam only aims at easing the life and society of human beings, solving their problems and not causing difficulty or unnecessary inconvenience. ${ }^{41}$ Thus, Wasatiyyah has been regarded as one of the basic principles for social life in Islam which undoubtedly promotes coexistence in an inclusive society.

\subsection{Responsibilities of Neighborhood}

Good neighborhood is an important ingredient of coexistence. It helps strengthening the community and establishing peace in the society. Bad neighborhood

${ }^{28}$ Yunus 10:9.

29 al-Ghashiya 88:21-22.

30 al-Ankaboot 29:18; al-Ghashiya 88: 21-22; al-Noor 24:54.

31 al-Baqarah 2:143.

32 al-Asr 103:3.

${ }_{34}^{33}$ Fussilāt 41:33.

34 al-Hajj 22:39.

35 al-Baqarah 2:201.

36 al-Arāf 7:31.

37 an-Nahl 16:25.

38 al-Baqarah 2:286.

39 al-Furqān 25:67; al-Isra 17:29.

40 al-Maida 5:6; al-Baqarah 2:185.

${ }^{41}$ Prophet $(S A W)$ said, "Surely, this deen is easy." For detail see: Abu Abd ar-Raḥ man al-Nasai, Sunan al-Nasai, Hadith no. 5034, online edition available at: https://sunnah.com/nasai/47/50. Accessed May 10, 2018.

JOURNAL OF ISLAMIC THOUGHT AND CIVLIZATION 
creates social insecurity and divisiveness. Good neighborhood manifests itself when positive relationships are built with members of different communities. Islam attaches paramount importance to the rights of the neighbor beyond religions, cultures or other differences. The duty towards the neighbor is only second in importance to the duties towards parents and near kindred. The Holy Qur'ān instructs, "And serve Allah. Ascribe nothing as partner unto Him. (Show) kindness unto parents, and unto near kindred, and orphans, and the needy, and unto the neighbor who is of kin (unto you) and the neighbor who is not of kin, and the fellow-traveler and the wayfarer and (the slaves) whom your right hands possess. Lo! Allah loveth not such as are proud and boastful." 42 The Prophet $(S A W)$ said that, "The best friend in the sight of Allah is he who is the well-wisher of his companions, and the best neighbor is one who behaves best towards his neighbors." 43 "He whoever passes his night satiated and restful in his home with his family, while he has poor neighbors passing their night hungry, has no true belief in the Messenger of Allah and is denying him too. Had such a man been a true believer, he would have given food to his neighbors and not let them pass the night in hunger." "The angel Gabriel continued to enjoin upon me good treatment of the neighbor, so much so that I thought he would make him heir to one's property." 45 Duties towards neighbors include kind treatment, safety from any harm caused by actions or words, giving gifts and food however small it may be, looking after in case of sickness and extending support if needed etc.

\subsection{Responsibilities towards Orphan, Disabled, Poor and Destitute}

Islam gives due importance to the rights of orphans, disabled, poor and destitute without any discrimination. The orphans should be accorded with kind treatment and due affection. The Holy Qur'ān says, “And let those [executors and guardians] fear [injustice] as if they [themselves] had left weak offspring behind and feared for them. So let them fear Allah and speak words of appropriate justice." 46 They should not be oppressed and discriminated against as the Holy Qur'ān says, "Indeed, those who devour the property of orphans unjustly are only consuming into their bellies fire. And they will be burned in a Blaze." "H7 "Have you seen him who goes against religion? That is the one who is rough to the orphan and does not urge the feeding of the needy." "The best home of Muslims is one where there is an orphan who is treated well; and the worst home of Muslims is one wherein there is an orphan who is treated badly." 49 High rewards are promised for those who treat orphans kindly. The Prophet $(S A W)$ said that "Whoso gives shelter to an orphan with his food and drink, Allah will guarantee him

42 an-Nisa 4:36.

${ }^{43}$ Abu Eisa al-Tirmidhi, Jami Tirmidhi, Hadith No. 1944. https://sunnah.com/tirmidhi/27/50. Accessed September 10, 2018.

${ }^{44}$ Sunan al-Kubra, Hadith no. 19049.

${ }^{45}$ Abu Dawud Sulayman, Sunan Abi Dawud, Hadith No. 5151.

https://sunnah.com/abudawud/43/379. Accessed September 10, 2018.

46 an-Nisa 4:9.

${ }^{47}$ Ibid., 4:10.

48 al-Ma'ūn 107:1-3.

${ }^{49}$ Ibn Maja, Sunan Ibn-Majah, Hadith No. 3679. https://sunnah.com/ibnmajah/33/23. Accessed September 10, 2018.

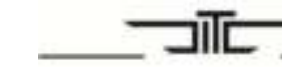

JOLRNAL OF ISLAMIC THOLGHT AND CIMLIZATION 
Paradise unless he has committed a sin which cannot be pardoned."50 "Who passes his touch over the head of an orphan, not passing it but for Allah, shall have merits for every hair over which his hand passes; and whoso shows kindness to an orphan-girl or a boy under his care, I and he shall be in Paradise like these two. And he joined together his two fingers." ${ }^{51}$ These Qur'ānic and Prophetic injunctions in this regard are very clear and no single verse differentiates between Muslims and non-Muslims. The Holy Qur'ān says, "They ask you, [O Muhammad], what they should spend. Say, 'Whatever you spend of good is [to be] for parents and relatives and orphans and the needy and the traveler. And whatever you do of good - indeed, Allah is Knowing of it." 52 Islam makes it obligatory for Muslims to help the people who are suffering from calamities, poverty, hunger and abode. "And they give food in spite of love for it to the needy, the orphan, and the captive, [Saying], 'We feed you only for the countenance of Allah. We wish not from you reward or gratitude." $" 53$ Nursing the sick is an important responsibility for every Muslim. The Prophet $(S A W)$ himself discharged all these duties without making any distinction. The Prophet $(S A W)$ said that "Feed the hungry, visit the sick and free captive."54 "The Almighty Allah would ask on the Day of Resurrection: O son of Adam! I was sick and you did not visit me. He will reply: O my Lord! How could I have visited Thee when Thou are the Lord of all the worlds. He will say: Did you not know that such and such of my servants was sick, but you did not visit him? Did you not know that if you had visited him, you would surely have found me with him?" 55 Islam has exempted the sick and disabled persons from performing several religious obligations. ${ }^{56}$ All these injunctions make it clear that the orphan, poor, disabled, destitute and the needy should be treated kindly and provided support without any discrimination. This teaching, in fact, would develop peaceful coexistence in the society. ${ }^{57}$

\subsection{Islamic Code of Social Behavior and Coexistence}

Islam prescribes a very well-defined code of conduct covering all aspects of human life and social behavior. It spontaneously promotes coexistence among diverse social groups. The Islamic code of correct social behavior includes truthfulness, ${ }^{58}$ sincerity, ${ }^{59}$ righteousness, ${ }^{60}$ unselfishness, ${ }^{61}$ humility, ${ }^{62}$ patience, ${ }^{63}$ forgiveness, ${ }^{64}$ honesty,

${ }^{50}$ Abu Dawood, Sunan Abi Dawud, Hadith No. 2871.

https://sunnah.com/abudawud/18/10. Accessed September 10, 2018,

${ }^{51}$ Abu Isa Muhammad b Isa Tirmidhi, Jami Tirmidhi, Hadith No. 3120.

https://sunnah.com/tirmidhi/22/66. Accessed September 10, 2018.

${ }_{53}$ al-Baqarah 2:215; an-Nisa 4:8; al-Anfāl 8:41.

53 al-Insān 76: 8-9.

${ }^{54}$ Bukhari, Sahih al-Bukhari, Hadith No. 3046. https://sunnah.com/bukhari/56/252. Accessed September 10, 2018.

${ }^{55}$ Muslim ibn al-Hajjaj, Sahih al-Muslim, Hadith No. 2569.

https://sunnah.com/muslim/45/54. Accessed September 10, 2018.

56 al-Baqarah 2:183; al-Baqarah 2:196; al-Maeda 5:6.

${ }^{57}$ For details, see Dr. Muhammad Sharif Chaudhry, Social and Moral Code of

Islam, online edition available at: http://www.shaufi.com/. Accessed June 15, 2017.

${ }_{59}^{58}$ al-Ahzāb 33:70; an-Nisa 4:135.

59 al-Saff $61: 3$

60 al-e-Imrān 3:92.

${ }^{61}$ Luqmān 31:18.

62 al-Furqān 25:63. 
cleanliness, ${ }^{65}$ kindness, ${ }^{66}$ consideration, ${ }^{67}$ respect for others, ${ }^{68}$ courage, moderation, ${ }^{69}$ cheerfulness, ${ }^{70}$ keeping promise, ${ }^{71}$ justice, ${ }_{75}^{72}$ greeting in well manner ${ }^{73}$ etc. It also tends to avoid harshness, cheating, ${ }^{74}$ falsehood, ${ }^{75}$ lying, harming others, stinginess, ${ }^{76}$ hardheartedness, disrespecting others, ${ }^{77}$ creating anarchy ${ }^{78}$ etc. ${ }^{79}$ In summary, Muslims should practice justice in every activity of society with everyone without any discrimination; should maintain good relations with all other social groups and should fulfill their promises and covenants within the framework of Islamic law. This code of conducts teaches Muslims the best social behavior that reforms society, encourages goodness, discourages injustice and most importantly strengthens coexistence among diverse groups of people living in a society.

\subsection{Islamic Code of Conduct with Non-Muslims and Coexistence}

Islam abolished all kinds of discrimination based on race, religion, nationality or language and granted full freedom to the religious practices of different groups. The Prophet $(S A W)$ granted complete freedom to the Jews of Medina and Christians of Najrān to perform their religious practices. Based on the several verses of the Holy Qur'ân and the traditions of the Prophet $(S A W)$, Dr. Muhammad Sharif Chaudhry summarized the rights of non-Muslims guaranteed by Islam as follows:

A. The lives, honor and properties of non-Muslims are protected by the Islamic state.

B. They have full freedom of religion, worship and to maintain their places of worship. They are also free to impart religious education to their children.

C. They have complete freedom to enjoy and maintain their culture, language, custom, tradition, mode of life, dress, etc.

D. They have judicial autonomy. Their mutual and personal matters be settled through their traditional and religious law.

E. All the agreements with them made by the Islamic state are fully maintained.

63 al-e-Imrān 3:145; 20:130; al-Ahzāb 33:48.

${ }_{65}^{64}$ al-e-Imrān 3:134.

65 al-Muddathir 74:4-5.

${ }_{67}^{66}$ Fussilāt $41: 34$.

67 al-Noor 24:27.

68 al-Baqarah 2:19.

69 al-Isra 17:29.

70 "It is an act of charity to meet your fellow with a cheerful face." Sahih al-Muslim,

Hadith No. 1506. https://sunnah.com/urn/2054250.Accessed May 10, 2018.

${ }_{72}$ al-Muminūn 23:8.

72 an-Nisa 4:58.

73 al-Baqarah 2:83.

74 al-Isra 17:34-35.

75 al-Baqarah 2:188.

${ }_{77}^{76}$ Muhammad 47:38; an-Nisa 4:36-37.

77 al-Hujurāt 49:12-13.

79 al-Baqarah 2:20.

79 al-Ahzāb 33:35.

${ }^{80}$ Those from whose tongue and hand people are safe. Abu Abd ar-Rah man al-Nasai, Sunan al-Nasai, Hadith no. 4995. https://sunnah.com/nasai/47/11. Accessed May 10, 2018.

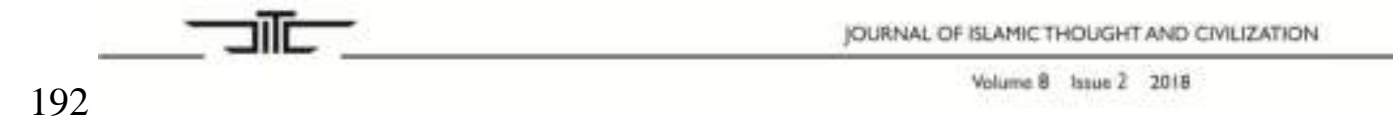


F. The poor and destitute among non-Muslims are entitled to financial assistance from the state like poor Muslims.

G. Muslims are also encouraged to be kind, helpful, tolerant and sympathetic to non-Muslims. ${ }^{81}$ Muslims can establish intimate social relations with them.

Undoubtedly, these instructions promote peaceful coexistence among all religious groups, Muslims and non-Muslims alike, living in a society, state or even in the world.

\subsection{Concept of Jihäd and Coexistence}

$J i h \bar{a}$, literally means to strive or to make efforts. It is to make efforts and to struggle in the way of God. Jihäd has two dimensions, the inner Jihäd that curbs negative and self-destructive forces within and the external Jihād that is against violence and tyranny by means of words, actions and struggles. This external Jihäd could exactly be expressed by the word Qitāl (war). Although war is permitted in Islam, it is permitted but with strict principles. War can only be waged for lawful purposes such as,

- In defense, when one is attacked.

- To eradicate corruption from the world.

- To eliminate persecution.

- To obtain moral, religious and physical freedom for oppressed people.

For achieving such noble causes, Muslims are permitted to wage war but they should strictly maintain certain rules during engagement with the enemy. These include:

- Non-combatants are not to suffer on account of war.

- Even against the combatants, one can only use that much force which is necessary to achieve the purpose but should not go beyond the limits. ${ }^{83}$

- If the enemy offers peace, one has no choice but to accept it and stop hostilities.

- One can't commit excesses or cruelties during the actual conduct of war.

- Arson and pillage are prohibited.

- Destruction of properties, plants and crops is forbidden.

- Killing of prisoners of war is prohibited and they should be treated generously.

- Women, children, the handicapped, and the aged ones should not be killed.

- All the terms of treaties and agreements should be strictly maintained.

- Places of worship should be honored. ${ }^{84}$

Although the Prophet Muhammad ( $S A W)$ had to participate in many wars, but the number of Muslims martyred during all the battles was less than 200. Moreover, less than 300 non-Muslims were killed. If these numbers are compared with the number of deaths during the World War I, it was about 10 million and during the World War II, it was about 20 million. During the war in Iraq, Afghanistan and Syria millions of people have been killed. Although, Islam permitted Jihäd but it is only for the establishment of peace

\footnotetext{
${ }^{81}$ The Prophet $(S A W)$ said: "Every act of kindness is sadaqa." Bukhari, Al-Adab alMufrad, online edition available at: https://sunnah.com/urn/2203040. Accessed May 10, 2018.

${ }^{82}$ For details, see, Dr. Muhammad Sharif Chaudhry, Social and Moral Code of Islam, online edition available at: http://www.shaufi.com/. Accessed May 10, 2017.

al-Baqarah 2:190.

${ }^{84}$ al-Hajj 22:39-40; al-Baqarah 2:193; al-Anfāl 8:61; al-Mumtahina 60:8.
} 
and welfare of the humanity. So, Jihād should be understood in its true perspective and should not be confused with other wars of the world. Islam considers the killing of an innocent person tantamount to the killing of whole humanity and saving one's life tantamount to giving life to all mankind. So, the true concept of Jihäd is not contrary to religious coexistence as it is misinterpreted in the west, rather true Jihäd promotes coexistence in the society by removing persecution, corruption and social anarchy.

\section{Peaceful Coexistence in Muslim Societies}

With these theoretical injunctions, Muslim society has set practical examples of coexistence between Muslims and non-Muslims in its history. The tolerant attitude and kind treatment extended by Muslims to non-Muslims remains a glorious chapter in the history of the world. Muslims and non-Muslims existed peacefully in Medina, the first Islamic State, as well as in the successive states. Many treaties were signed between Muslims and non-Muslims which were executed with utmost respect. Some examples of socio-religious coexistence in the early history of Muslim societies are being discussed below.

\subsection{During the Time of Prophet Muhammad $(S A W)$}

\subsubsection{The Charter of Medina}

The first ever written constitution in the history of the world ${ }^{85}$ set the best example for the establishment of peaceful coexistence among different religious groups not only in the history of Islam but also in that of mankind. It was executed for 10 years (622-632 A.D.) under the leadership of the Prophet Muhammad $(S A W)$ and aimed at governing a multi-religious pluralistic society. Different religious communities (Jews, Pagans, Christians, and Muslims) that showed enmity towards one another for several centuries became parties to the pact and started living together in a single society, peacefully. Remarkably, $45 \%$ of the total population in Medina at that time comprised non-Muslim Arabs, $40 \%$ comprised Jews and only $15 \%$ comprised Muslims. ${ }^{86}$ Prophet Muhammad $(S A W)$ executed the charter as a leader of minority. The charter had 47 clauses and it formed a sovereign nation-state with a common citizenship for every individual of all communities. The charter protected the fundamental human rights of all citizens, including equality, freedom of conscience and freedom of religion. It said:

Article 25: The Jews shall have their own religion and the Muslims their own. (This applies) to their clients and, to themselves with the exception of anyone who does wrong or acts treacherously; he brings evil on himself and his family members.

Article 37: Each must help the other against anyone who attacks the people of this document. They must seek mutual advice and consultation. And loyalty is a protection against treachery. A man is not liable for his ally's misdeeds. The wronged must be helped.

Article 40: The protected neighbor (jar) is as sacred as the protector himself as long as he does not harm and does not act treacherously.

${ }^{85}$ Yetkin Yildirim, "Peace and Conflict Resolution in the Medina Charter," Peace Review 18, no. 1 (2006): 109-117.

${ }^{86}$ Sean William White, The Constitution of Medina: A Symbol of Pluralism in Islam, online edition available at: https://themuslimtimes.info/2012/11/09/the-constitution-of-medina-asymbol-of-pluralism-in-islam/. Accessed May 10, 2017.

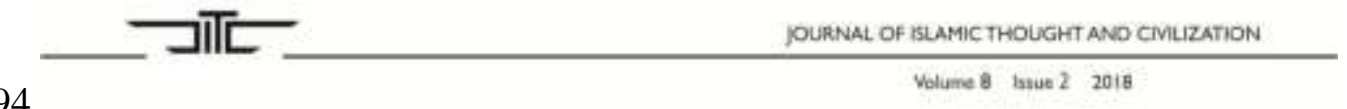


Article 42: If any dispute or controversy likely to cause trouble should arise among the people of this document, it must be referred to Allah and Muhammad. Allah will guarantee the observance of this document.

Article 46-47: Whoever among the Jews follows us shall have help and equality; they shall not be injured nor shall any enemy be aided against them. The Jews maintain their religion and the Muslims theirs. Among the Jews (belonging to different tribes), and so with their adherents; those who transgress and behave unjustly and sinfully hurt but themselves and their families. Loyalty is a protection against treachery. The close friends of Jews are as themselves. Each, if attacked, shall come to the help of the other. The valley of Yathrib (Medina) shall be sacred and inviolable for all who join this treaty.

Strangers under protection shall be treated on the same grounds as their protectors.

According to the treaty, everyone enjoyed freedom to adhere to any religious belief and practice his own justice system. It considered Muslims, Jews, Christians and heathens as one society working for the welfare of all. The charter abolished the tribal structures which had formerly been based on blood and kinship and brought belligerent tribes of different religious, ethnic and geographical origins together. It acknowledged religious freedom as a fundamental right, being the first document to incorporate it in the constitutional history of the world. The treaty extended protection to life, property, belief, liberty and religion to all. It offered equal rights and responsibilities to all citizens. "The charter replaced the traditional tribal kinship with a new social order and created a nation state with a new social fabric. This epoch-making innovation ... brought an end for all times to the chaos of tribalism and laid the basis for a wider institution, viz a State." 88 Medina has been marked as the first practical example of peaceful coexistence between different religions and groups in Islam. "Peace was achieved in Medina, through the principles of coexistence in Islam, including tolerance, love, reason, and a belief in God, whether the God in the Bible, the Qur'ān, or the Torah."90

\subsubsection{Covenant with the Christians of Najrān}

Another enlightened example of tolerance is the covenant of the Prophet Muhammad $(S A W)$ with the monks of the monastery of St. Catherine and all Christians. The Prophet $(S A W)$ gave full freedom to the Christians of Najrān to offer prayers in their own way in the Mosque of Medina. ${ }^{91}$ After several rounds of negotiation, the treaty of Najrān was signed which conferred on the non-Muslims both religious and administrative

${ }^{87}$ Muhammad Nazeer Kaka Khel, "Foundation of the Islamic State at Medina and its Constitution," Islamic Studies 21, no. 3 (1982): 76-80.

${ }^{88}$ Muhammad Hamidullah, The First Written Constitution in the World: An Important Document of the Time of the Holy Prophet SAW (Lahore: n. p. 1975).

${ }^{89}$ Abdulaziz Sachedina, The Islamic Roots of Democratic Pluralism (New York: OUP, 2001), 26.

${ }^{90}$ Sean William White, Medina Charter of Prophet Muhammad and Pluralism, online edition available at: http://www.islamicity.org/5685/medina-charter-of-prophet-muhammad-andpluralism/ Accessed May 10, 2017.

${ }^{91}$ Muhammad Ibn Ishāq, The Life of Muhammad: A Translation of Ibn Ishāq's Sirat Rasul Allah, trans., Alfred Guillaume (UK: Oxford University Press, 1987), 271. 
autonomy. ${ }^{92}$ Relevant portion of Prophet's ( $\left.S A W\right)$ letter to the Christians of Najrān is as follows:

The lives of the people of Najrān and its surrounding area, their religion, their land, property, cattle and those of them who are present or absent, their messengers and their places of worship are under the protection of Allah and guardianship of His Prophet $(S A W)$. Their present state shall neither be interfered with, nor their rights meddled with, nor their idols deformed. No bishop shall be removed from his bishopric, nor any monk from his priesthood, and they shall continue to enjoy everything great and small as heretofore; no image or cross shall be destroyed, they shall not be oppressed or suppressed. They shall be punished for any past crime. No tithes shall be levied on them nor shall they be required to furnish provisions for the troops, nor shall troops be quartered on them. Whatever has been written in this pact, Allah and Muhammad His

Prophet $(S A W)$ are guarantors of it. 93

This document displays how Islam guaranteed religious liberty and rights of other groups. By this accord, the Prophet $(S A W)$ extended strict security to the privileges and immunities of Christians. He undertook himself and guided his followers to protect the rights of Christians, to defend their churches and the residences of their priests. They were not to be unfairly levied, no bishop was to be driven out, no monk was to be expelled, no church was to be pulled down, and no Christian was to be converted forcefully. The Christian women who married Muslims were entitled to enjoy freedom to observe their own religion. If Muslims be engaged in hostilities with the Christians of another territory, no Christian resident living in Muslim state be treated with contempt. Any Muslim who violates this covenant, will be accounted recalcitrant to God and Prophet Muhammad (SAW).

- After the conquest of Mecca, when the Prophet $(S A W)$ entered into the city, he forgave them in these words, "No blame will there be upon you today. Allah will forgive you; and $\mathrm{He}$ is the most merciful of the merciful." 94

- It was narrated that, "A funeral procession passed by the Holy Prophet $(S A W)$ and he stood up for it. People said to him: It was the funeral of a Jew. He said: Was it not a human life?"95

\subsection{During the time of Four Pious Caliphs (632-661 A.D.)}

Perhaps the best example of socio-religious coexistence in the early history of Islam was set by Umar $(R A)$, the second Caliph of Islam. Arab Muslims came in contact with large numbers of Christians and Jews after the conquest of Iraq, Syria and Egypt. Damascus surrendered in 635 A.D., Iraq in 637 A.D., Jerusalem in 638 A.D., and Alexandria in 641 A.D. In dealing with an overwhelming Christian population there,

${ }^{92}$ Saleh Al-Aayed, The Rights of Non-Muslims in Islam: An Islamic Basis, online edition available at: http://www.islamreligion.com/articles/374/viewall/rights-of-non-muslimsin-islam/\# ftn26367. Accessed May 10, 2017.

${ }^{9 \overline{3}}$ Craig Considine, Religious Pluralism and Civic Rights in a "Muslim Nation: An Analysis of Prophet Muhammad's Covenants with Christians, online edition available at: https://en.wikisource.org/wiki/An_Analysis_of_Prophet_Muhammad\%E2\%80\%99s_Covenants_ with_Christians Accessed May 10, 2017.

${ }^{94}$ Yusuf 12:92.

${ }^{95}$ Bukhari, Sahih al-Bukhari, Hadith No. 1311. https://sunnah.com/bukhari/23/70. Accessed September 10, 2018. 
Arab Muslim commanders and Caliph Umar $(R A)$ followed the example set by the Prophet $(S A W)$. Khalid ibn al-Walīd $(R A)$, the Muslim commander to whom Damascus surrendered, issued the following declaration to the people of Damascus:

In the name of Allah, the compassionate, the merciful. This is what Khalid ibn al-Walid would grant to the inhabitants of Damascus if he enters therein; he promises to give them security for their lives, property, and churches. Their city shall not be demolished; neither shall any Muslim be quartered in their houses. Thereunto we give them the pact of Allah and the protection of his Prophet $(S A W)$, the caliphs, and the believers. So long as they pay the poll tax, nothing but good shall befall them. 96

The fall of Jerusalem was not substantially different. Following the retreat of the Byzantine army, the city came under the control of Patriarch Sophronius, who refused to surrender the city except to Caliph Umar. Accordingly, Caliph Umar travelled from Medina to receive Jerusalem ${ }^{97}$ and signed an agreement with the local Christians which read as follows,

In the name of Allah, the Gracious, the Merciful. This is what is granted of security by the servant of Allah, Umar, the commander of the faithful, to the people of Jerusalem. He grants to all, whether sick or sound, safety for their lives, their property, their churches, and their crosses, and for all that concerns their religion. Their churches shall not be changed into dwelling places, nor destroyed, neither shall they nor their appurtenances be in anyway diminished, neither the crosses of the inhabitants nor aught of their possessions, nor shall any constraints be put upon them in the matter of their faith, nor shall any one of them be harmed. 98

After the conquest of Jerusalem, there was a time of prayer. Caliph Umar was requested by the patriarch to offer prayer inside the church. Umar refused saying that, "if I do so, the Muslim may infringe upon your rights in a future age pretending to follow my example." Instead, he offered prayer at the steps outside. ${ }^{99}$

After the conquest of Iraq, the soldiers wanted to divide the fertile agricultural land among themselves as a part of war booty. Caliph Umar rejected the idea saying, "I want a situation that will be good for the people of present and future." He decreed that the land should have a tax levied on its production and it should remain in the hands of its people who would pay the tax to the state treasury. He reinforced the policy of tolerance and coexistence with non-Muslims. Under the Byzantines, Jews were barred from Jerusalem, while Muslims allowed them to enter it again. ${ }^{100}$ During the time of Umar, certain Muslims had taken a piece of land which belonged to a Jew and they constructed a mosque there. Umar $(R A)$ ordered to demolish the mosque and to return the land to the Jew.

In the reign of Othman $(R A)$ the third Caliph of Islam, the Christian patriarch of Merv addressed the bishop of Fars, named Simeon, in the following words, "the Arabs who been given by God the kingdom do not attack the Christians' faith; on the contrary

\footnotetext{
${ }^{96}$ Philip K. Hitti, History of the Arabs (London: Macmillan, 1990), 150.

${ }^{97}$ Ibid., 154.

${ }_{99}^{98}$ Francis Edward Peters, Jerusalem (Princeton: Princeton University Press, 1985), 258.

${ }^{99}$ Ishtiaq H. Qureshi, The Religion of Peace (Karachi: Royal Book Company, 1989), 102.

${ }^{100}$ John Esposito, Islam, the Straight Path (UK: Oxford University Press, 1988), 63.
} 
they help us in our religion, they respect our god and our saints, and bestow gifts on our churches and monasteries."101

4.3. During the Umayyads and Abbasids (661-750 A.D. and 750-1258 A.D.)

The successor Muslim states also followed the policy of tolerance and coexistence with different religious and cultural groups living in their territory. Will Durant has remarked that:
At the time of the Umayyad Caliphate, the people of the covenant, Christians, Zoroastrians, Jews, and Sabians, all enjoyed degree of tolerance that we do not find even today in Christian countries. They were free to practice the rituals of their religion and their churches and temples were preserved. They enjoyed autonomy in that they were subject to the religious laws of the scholars and judges. 102

Some examples are given below.

i. Non-Muslims were given citizenship in Muslim country in which they lived and enjoyed all civil rights equal to Muslims.

ii. During the rule of Umayyads and Abbasids, no discrimination was made against nonMuslims, rather they were given several positions in the political and administrative offices. Non-Muslims were given judicial autonomy, not only in personal status, but in all affairs of their life, i.e., civil, penal and others. During the Abbasids, Christian Patriarchs and Jewish Hakhams (Rabbis) held the position of advisors in the cabinet of the Caliph himself. "The dhimmis (non-Muslims living in Islamic state) enjoyed a wide measure of toleration. Even in matters of civil and criminal judicial procedure... these people practically lived under their own spiritual heads."103

iii. When the Muslim army reached the valley of Jordan and Abu Ubaydah set his camp at Fihl, the Christian inhabitants wrote to them, "O Muslims, we prefer you to the Byzantine though they are of our faith, because you keep better faith with us and are more merciful to us and refrain from doing us injustice and your rule over us is better than theirs, for they have robbed us of our goods and our homes."104

iv. Mu'awiyah (RA) (661-680 A.D.), the founder of Umayyad caliphate, employed a good number of Christians in his services and the successive rulers of the Umayyad and Abbasid dynasties also followed his example. Christians and Jews frequently held high positions at the court. Even in the cities Christians and Jews often held important financial, clerical and professional positions. This often led to open jealousy on the part of the Muslim populace and found expression in official enactments. But most of this discriminating legislation remained 'ink on paper' and was not consistently enforced. ${ }^{105}$ Al-Muttaqi (940-944) had a Christian vizir, Al-Mutadid (892-902) had a Christian as

\footnotetext{
${ }^{101}$ Shittu Balogun Abdulazeez, "Peaceful Coexistence in a Multi-Religious Society: Islam and Christianity Perspectives," International Journal of Islamic Thoughts 2 (2013): 50.

${ }_{103}$ Will Durant, The Story of Civilization, Vol. 4 (Simon and Schuster, 1975), 131-132.

${ }_{103}$ Philip K. Hitti, History of the Arabs, 233.

${ }^{104}$ Harun Yahya, Islam Denounces Terrorism (New Delhi: Adam Publishers, 2003), 46.

${ }^{105}$ Philip K. Hitti, History of the Arabs, 353.
}

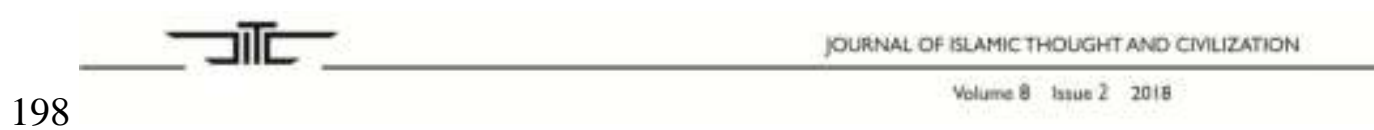


head of the war office. Such Christian high officials received the usual marks of honor. Most of the personal physicians of the Caliphs were members of the Nestorian Church. ${ }^{106}$ v. During the days of Umar ibn Abd-al-Aziz (717-720 A.D.), some Muslims took a church to enlarge the Grand Mosque of Damascus. The caliph ordered to demolish the extended part of the mosque and to restore the church. ${ }^{107}$

vi. During the days of famous Abbasid Caliph Haroon Al-Rashid (786-809 A.D.), Dr. Gabriel, the personal physician of the Caliph was a Nestorian Christian. ${ }^{108}$ In 985 A.D., al-Maqdisi found most of the money-changers and bankers in Syria to be Jews, and most of the clerks and physicians to be Christians. ${ }^{109}$

\subsection{Examples from Later and Other Contemporary Muslim Societies}

The later Muslim states and societies also set good examples of peaceful coexistence between Muslims and non-Muslims. Christians and Jews lived peacefully with Muslims in Islamic states. The frequent presence of a large number of Christians and Jews in the Muslim world throughout the course of history is a sign of tolerance of Muslims extended towards non-Muslims.

1. The Fatimid Caliphate (969-1171 A.D.) in Egypt was noted for its tolerant attitude towards Christians and Jews, except for the rule of Caliph al-Hakim (996-1021 A.D.). Several Jewish and Christians reached the second highest position, that is the Wazir, in the state. Ya'qub ibn-Killis and Hasan Ibrahim, both were Jews who converted to Islam and assumed that office. Ibn-Killis' expert administration laid the basis of economic prosperity of the Nile valley under the early Fatimids. ${ }^{110}$ Four Christians filled the position as Christians, with one even carrying the title of Saif al-Islam, or 'sword of Islam.' Badr al Jamali, an Armenian Christian slave, served Caliph al-Mustansir (1036 94 A.D.) as governor of Syria, carried the title of 'Wazir of the sword and pen,' equivalent to minister of defense and civil service.

2. Spain was ruled by Muslims for about seven centuries (711-1492 A.D.) and set one of the most excellent examples of peaceful coexistence of various cultures and religions. On their arrival in Spain, the Muslims published an edict confirming to the subject races, without any difference of race or creed. Suevi, Goth, Vandal, Romans, and Jews were given equal rights with Muslims. They guaranteed both Christians and Jews full exercise of their religions, free use of their houses of worship and security of person and property. Christians and Jews, along with Muslims, shared in the wealth of Cordoba, the capital of Muslim Spain and occupied high positions in the royal court. ${ }^{111}$ In the words of Zachary Karabell, "In the towns and cities, Jews found themselves in unique positions as intermediaries between Muslim-dominated Spain and the rest of the world. Having suffered severe discrimination at the hands of the Visigoths, Jewish communities

\footnotetext{
${ }^{106}$ Ibid., 355.

${ }^{107}$ Ibn Abd al-Hakam, Sirat Umar Ibn Abd al- Aziz, ed. A. Abid (Cairo: n. p.,1927), 178.

${ }^{108}$ Ahmad H. Sakr, Non-Muslims in Muslim History, online edition available at: http://www.islamicity.org/7681/non-muslims-in-muslim-history/ Accessed May 10, 2017.

${ }_{109}^{10}$ Philip K. Hitti, History of the Arabs, 356.

110 Ibid., 627.

${ }^{111}$ Zachary Karabell, Peace Be upon You: The Story of Muslim, Christian, and Jewish Coexistence (New York: Knopf, 2007). 69.
} 
under the Muslims enjoyed more freedom, affluence, and social standing than any Jewish community would until the $19^{\text {th }}$ century." 112

Patriarch Ghaytho wrote that "The Arabs, to whom the Lord has given control over the world, treat us as you know; they are not the enemies of Christians. Indeed, they praise our community, and treat our priests and saints with dignity, and offer aid to churches and monasteries." 113 The high culture of coexistence was manifested with Spanish Arab Muslims frequently marrying the Christians:

A melding of Christian, Jewish and Muslim traditions created its culture. Each group contributed its best, thrived and prospered, while maintaining its separate religious tradition. Churches, synagogues and mosques were open to worshippers; those who were atheists coexisted with believers... Rightly so it is considered an epitome of a state based on universal religious principles, accommodating and accepting citizens irrespective of their faith. 114

Muslim rule in Spain broke the power of the privileged group, including the nobility and clergy, ameliorated the condition of the servile class and gave the Christian landowner such rights as the alienation of his property which he was denied under the Visigoths. 115

3. During the occupation of the Middle East by the crusaders, the local Christians were treated as second class citizens by their European brethren. Therefore, they helped the Muslims to get rid of the crusaders from their area, mainly Jerusalem and Palestine. They helped Salahuddin Ayubi to liberate Jerusalem from the occupation of the crusaders. He treated the knights and their soldiers with honor and dignity. They appreciated his kindness, generosity and fair treatment. ${ }^{116}$

Thus, it may confidently be said that Muslim societies in different parts of the world and in the course of their history set the best examples of religious tolerance and social coexistence. Non-Muslim citizens living in the Muslim countries enjoyed complete freedom of religion and frequently attained high positions in the administrative offices. W. Montgomery Watt acknowledged that, "On the whole there was more genuine toleration of non-Muslims under Islam than there was of non-Christians in Medieval Christians states." 117

${ }^{112}$ Ibid., 71.

${ }^{113}$ Arthur Stanley Tritton, The People of the Covenant in Islam, 158.

${ }^{114}$ Pervez Hoodbhoy, "Islam and Pluralism In The Modern Muslim State," in Islam and Pluralism (Harvard: 2011) online edition available at: http://eacpe.org/content/uploads/2014/02/Islam-and-pluralism-in-the-modern-Muslim-state.pdf Accessed May 10, 2017.

${ }_{116}$ Philip K. Hitti, History of the Arabs, 510.

${ }^{116}$ Ahmad H. Sakr, Non-Muslims in Muslim History.

${ }^{117}$ Abdul Majid, Peaceful Coexistence of Various Cultures and Religions: An Islamic Perspective with Special Reference to Spain, 2008. online edition available at:http://www.metanexus.net/essay/peaceful-co-existence-various-cultures-and-religions-islamicperspective-special-reference. Accessed June 21, 2017.

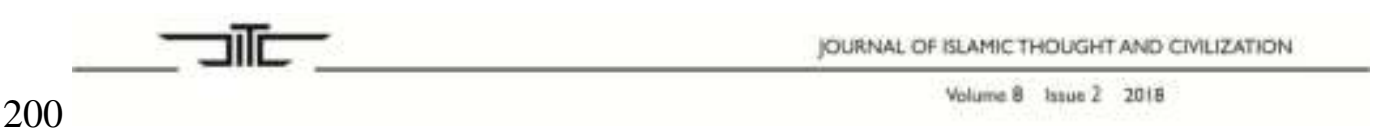




\section{Conclusion}

Coexistence of diverse socio-religious groups and tolerant attitude of a group towards the other(s) is one of the fundamental ingredients for the establishment of peace and security in the society. From the above discussion, it becomes very clear that the teachings of Islam very much promote the principles of peaceful coexistence. It not only allows non-Muslims to perform their religious practices in their religious houses, but also provides complete security to their lives, properties and dignities. It extends equal rights of citizenship to Muslims and non-Muslims without any discrimination based on caste, creed or culture. The Charter of Medina has rightly been termed as 'the first constitutional document providing equal rights to all the people living in a country.' The Prophet $(S A W)$ himself set the best ever examples of communal coexistence and religious tolerance during his lifetime through different treaties, declarations, covenants and practices. The successive Muslim states and societies in different parts of the world also set remarkable examples of peaceful coexistence. From the historical experience, it can confidently be said that the treatment offered by Muslim states to other religious communities particularly to the Christians and Jews was far superior to the treatment that Muslims have received at the hands of Christian states or at the hands of the Jewish state of Israel. Robert Haddad in his book Syrian Christians in Muslim Society states that, "Islamic tolerance served to insure Christian survival."118 "No attempt was made by any Muslim government to exterminate the Christians." "119 Zachary Karabell states that, "for a millennium and a half, until the end of World War II, Jews under Muslim rule enjoyed more safety, freedom, and autonomy than they ever did under Christian rule. Muslim States over the course of fourteen centuries have allowed for religious diversity and not insisted on trying to convert those who follow a different creed." ${ }^{, 120}$ Thus, it can be said, in conclusion, that Islam neither supports nor promotes religious intolerance. The current trend of religious intolerance and extremist attitude around.

\section{Bibliography}

al-Aayed, Saleh. "The Rights of Non-Muslims in Islam: An Islamic Basis." 2016. http://www.islamreligion.com/articles/374/viewall/rights-of-non-muslims-inislam/\#_ftn26367.

Abdulazeez, Shittu. "Peaceful Coexistence in a Multi-Religious Society: Islam and Christianity Perspectives.” International Journal of Islamic Thoughts 2 (2013).

Abdul Majid. "Peaceful Coexistence of Various Cultures and Religions: An Islamic Perspective with Special Reference to Spain.” 2008.

http://www.metanexus.net/essay/peaceful-co-existence-various-cultures-andreligions-islamic-perspective-special-reference.

Abou-Seade, Abdel Hameed. "Byzantium and Islam $\left(9^{\text {th }}-10^{\text {th }}\right.$ centuries) A Historical Evaluation of the Role of Religion in Byzantine-Muslim Relations." PhD Thesis, School of Historical Studies, The University of Birmingham, 2010.

${ }^{118}$ Robert Haddad, Syrian Christians in Muslim Society (New Jersey: Princeton University Press, 1970), 5.

${ }^{1}$ Ibid., 8.

${ }^{120}$ Zachary Karabell, Peace Be upon You, 8. 
Islam Peaceful Coexistence of Various Religious Groups in Islam

Adesokan, Toyese Abdurahman. "An Appraisal of Peaceful Coexistence between Muslims and Non-Muslims in Houston Texas of USA." E-Journal of Arabic Studies and Islamic Civilization 2 (2015)

Considine, Craig. "Religious Pluralism and Civic Rights in a "Muslim Nation": An Analysis of Prophet Muhammad's Covenants with Christians." 2016. https://en.wikisource.org/wiki/An_Analysis_of_Prophet_Muhammad\%E2\%80\% 99s_Covenants_with_Christians.

Durant, Will. The Story of Civilization. New York: Simon and Schuster, 1975.

Elias, Abu Amina. "Protection of non-Muslim Houses of Worship in Islam." 2015, https://abuaminaelias.com/protection-of-non-muslim-houses-of-worship-inislam/.

Esposito, John L. Islam, the Straight Path. London: Oxford University Press, 1988.

Hamidullah, Muhammad. The First Written Constitution in the World: An Important Document of the Time of the Holy Prophet. Lahore: Sh. Muhammad Ashraf Publications, 1975.

Hoodbhoy, Pervez. "Islam and Pluralism in the Modern Muslim State." In Islam and Pluralism. 2011. http://eacpe.org/content/uploads/2014/02/Islam-and-pluralismin-the-modern-Muslim-state.pdf.

Hitti, Phillip. History of the Arabs. London: Macmillan, 1990.

Haddad, Robert. Syrian Christians in Muslim Society. New Jersey: Princeton University Press, 1970.

Ibn Ishāq, Muhammad. The Life of Muhammad: A Translation of Ibn Ishāq's Sirat Rasul Allah. Translated by Alfred Guillaume. London: Oxford University Press, 1987.

Karabell, Zachary. Peace Be upon You: The Story of Muslim, Christian, and Jewish Coexistence. New York: Knopf, 2007.

Khaminwa, Angela. "Coexistence." Beyond Intractability. Edited by Guy Burgess and Heidi Burgess. Conflict Information Consortium. University of Colorado, 2003.

Kriesberg, Louis. "Coexistence and the Reconciliation of Communal Conflicts." In The Handbook of Interethnic Coexistence. Edited by Eugene Weiner. New York: Continuum International Publishing Group, 1998.

Nazeer Kaka Khel, Muhammad. "Foundation of the Islamic State at Medina and its Constitution." Islamic Studies 21, no. 3 (1982).

Peters, Francis. Jerusalem. Princeton: Princeton University Press, 1985.

Qureshi, Ishtiaq. The Religion of Peace. Karachi: Royal Book Company, 1989.

Rupesinghe, Kumar. "Coexistence and Transformation in Asia: Some Reflections." In Culture and Identity: Ethnic Coexistence in the Asian Context. Edited by Kumar Rupsinghe. Washington DC: The Sasakawa Peace Foundation, 1999.

Sachedina, Abdulaziz. The Islamic Roots of Democratic Pluralism. New York: OUP, 2001.

Sharif, Muhammad. Social and Moral Code of Islam. http://www.shaufi.com/.

Weiner,Eugene. "Coexistence Work: A New Profession." In The Handbook of Interethnic Coexistence. Edited by Eugene Weiner. New York: Continuum International Publishing Group, 1998.

JOURNAL OF ISLAMIC THOLGHT AND CIMLIZATION

202 volume 8 taue 22018 
Islam Peaceful Coexistence of Various Religious Groups in Islam

White, Sean William. The Constitution of Medina: A Symbol of Pluralism in Islam. 2012. https://themuslimtimes.info/2012/11/09/the-constitution-of-medina-a-symbol-ofpluralism-in-islam/.

Yahya, Harun. Islam Denounces Terrorism. New Delhi: Adam Publishers, 2003.

Yildirim, Yetkin. "Peace and Conflict Resolution in the Medina Charter." Peace Review 18 , no. 1 (2006). 
